\title{
Kerekasztal-beszélgetés középiskolásokkal olvasási szokásokról, attitüdökről, élményekről
}

\author{
Magyar Ágnes \\ Eszterházy Károly Egyetem
}

A fókuszcsoportos beszélgetés célja, körülményei

A Kutatók Éjszakája programsorozat keretében 2017. szeptember 29-én Kit érdekel, mit olvasol? címmel kerekasztal-beszélgetésre hívtuk a középiskolás fiatalokat az Eszterházy Károly Egyetem Jászberényi Campusára. Olvasási szokásokról, attitüdökről, olvasmányélményekről kérdeztük őket. A rendezvényt hagyományteremtő céllal szerveztük, s további motivációink voltak, hogy lehetőséget teremtsünk a középiskolások számára a kapcsolatépítésre, az olvasással kapcsolatos élmények, gondolatok, érzések, tapasztalatok megosztására, kedvébresztésre és ötletadásra, olvasmányajánlásra egymásnak. Többek között olyan kérdéseket érintettünk, mint hogy ki, mit, mikor, milyen körülmények között, hol, miért, hogyan, milyen formában olvas szívesen? Melyik a meghatározó? A történet? A szerző? A terjedelem? A müfaj? Mindegyik? Egyik sem? Valami más?

A fókuszcsoportos beszélgetés során - a résztvevők beleegyezésével - az elhangzottakról hangfelvétel is készült azzal a céllal, hogy a megkérdezettek válaszait összehasonlíthassuk egy 2012-ben készült strukturált interjúsorozattal. Akkor lényegesen más szituációban, egyenként, és sokkal kötöttebb formában beszélgettünk középiskolásokkal olvasási szokásaikról, ezért érdemesnek találtuk vizsgálni, hogyan változik a beszélgetés menete, jellege és a kapott válaszok minősége a kontextus változtatásával.

A beszélgetésre a jászberényi középiskolákból tizenkét tanuló jött el. A létszám elsőre kevésnek tünhet, de a részvételi szándékot befolyásolta, hogy a program időpontja sajnos egybeesett több, középiskolások tömegeit megmozgató más eseménnyel (pl. Szántai Kupa; Ökonap), ugyanakkor egy fókuszcsoportos beszélgetéshez épp ideális volt a résztvevők száma, hiszen így biztosítani lehetett mindenki számára a megszólalás lehetőségét. 
Magyar Ágnes

Kritikusak önmagukhoz

Arra a kérdésre, hogy hogyan jellemeznék saját korosztályuk olvasási szokásait, eléggé változatos válaszokat adtak. Volt, aki azt mondta, hogy a mostani középiskolások is olvasnak, hiszen minden olyan tevékenység olvasásnak minősül, terjedelemtől, minőségtől, szövegtípustól és eszközhordozótól függetlenül, melynek során szöveges információfeldolgozás történik. Ezzel teljesen ellentétes vélemény is érkezett, miszerint ez a korosztály (a tanuló saját osztálytársaira gondolt) nem is tud olvasni, hiszen mást sem csinálnak, csak a telefont nyomkodják. Nem ennyire szélsőséges, de ehhez közeli álláspontot képviseltek többen is, mondván, hogy a mai fiatalokat nem érdekli az olvasás, más dolgok felé fordultak, szabadidejüket szívesebben töltik más elfoglaltságokkal, például a digitális technológia eszközei nyújtotta kikapcsolódási lehetőségekkel, illetve többen mondták azt is, hogy nem sok szabadidejük van a tanulás és a tanórán kívüli elfoglaltságok mellett. Abban szinte egyöntetüen egyetértettek, hogy az internet az alapvető tájékozódási forrásuk, és az olvasmányok kiválasztásában meghatározó szerepet játszanak a közösségi oldalon terjedő információk.

\section{Elötérben az online olvasás}

Az online olvasás tehát kiemelkedő szerepet játszik a tizenévesek körében. A beszélgetés során különböző pontokon is érintettük ezt a témát. Felvetődött például, hogy milyen szerepe van a közösségi oldalaknak, és föként a Facebooknak az olvasás alakításában. A beszélgetés résztvevői soroltak pozitív hatásokat: például az öket érdeklő témákat megjelenítő oldalakat lájkolva könynyen találhatnak a témában cikkeket, írásokat. A közösségi oldalon lehetöségük van olyan zárt vagy nyílt csoportokhoz is csatlakozni, ahol hasonló érdeklődési körrel rendelkező olvasókkal teremthetnek kapcsolatot, találnak itt könyvkritikákat, és olvasmányajánlókat is megoszthatnak egymással. Néhányan említették, hogy egy-egy olvasmányt, akár könyvet, le is szoktak tölteni, és tableten vagy e-book formájában olvassák azokat. A fan fiction-ról kevesen hallottak a beszélgetésben részt vevők közül, pedig egy kifejezetten új, internetes müfajról van szó. A fan fictionok úgynevezett rajongói átírások, egy-egy népszerü történet, könyv (pl. Harry Potter) alternatív variánsait jelentik. Léteznek weboldalak (pl. Merengö), melyek az ilyen típusú írások tárhelyei, és fan fiction író pályázatokra, valamint táborokra is van példa Magyarországon is. A tanuláshoz való információgyüjtés elsődleges forrása az internet, de azért azt többen is elismerték, hogy az online olvasás nem helyettesítheti a papíralapút, hiszen a 
neten böngészve nagyon sok olyan zavaró tényező van (vizuális információk, felugró ablakok, párhuzamosan futó oldalak), amely eltereli a figyelmüket az olvasásról, illetve más irányba terelik az információgyüjtés menetét.

\section{Kedvenc témák, müfajok}

Arra a kérdésre, hogy mit olvasnak szívesen, egy mondattal a következöképpen lehetne válaszolni: mindent, ami elrugaszkodik a realitástól, a valós történeteket, dokumentumszövegeket nem preferálják. Kedvenc olvasmányaik a következő müfajokból és témákból kerülnek ki: vámpíros, megfoghatatlan, fantáziavilág, fantasy, thriller, horror, szerelmes regény, lányregény, romantikus, sci-fi, misztikus, anime, manga, kalandregény, mondanivalóval bíró történetek. A 2012-es strukturált interjúk eredményeivel összehasonlítva a mostani válaszokat, arra a következtetésre juthatunk, hogy a kedvelt olvasmányok fő motívumai nem változtak az elmúlt öt évben. 2012-ben az izgalmas, fordulatos, pörgős, haladós cselekményvezetés, a nem túl hosszadalmas, részletező kifejtés nagyon sok válaszban szerepelt. Fontos, hogy maga a téma érdekes legyen, semmiképp sem unalmas, felkeltse az olvasó figyelmét, érdekeltté tegye az olvasásban. A lányok inkább emelték ki az érzelmes jelleg fontosságát, míg a fiúknál fontos a felépítés, a kidolgozottság. Néhányuknál az elgondolkodtató, a tanulságos, a hiteles vagy az újat mondó szövegek élveznek elönyt, míg másoknál a fantázia, a humor vagy a titokzatosság a kedvelt motívum. Azok, akik sokat olvasnak kedvtelésből, szeretik, ha egy olvasmány hosszú, és sokáig tart elolvasni, míg a kevesebbet olvasók inkább annak örülnek, ha rövidebb a szöveg (1. 1. ábra) (Magyarné, 2013).

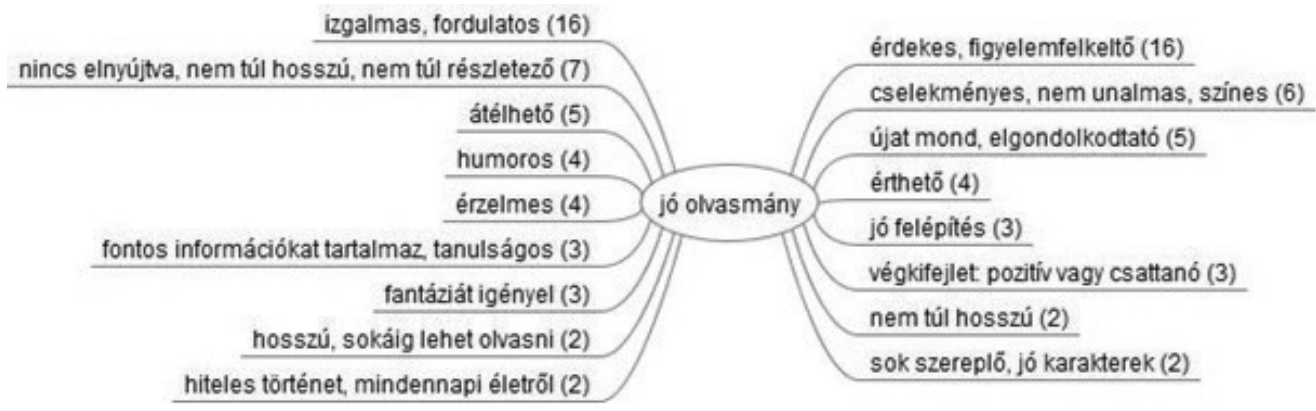

1. ábra: A jó olvasmány motívumai (2012) 
Magyar Ágnes

Az olvasás motivációi

Arra a kérdésre, hogy milyen indíttatásból olvasnak, legtöbben azt válaszolták, hogy szeretnek elrugaszkodni a valóságtól, elvonulni egy másik világba, ahol kikapcsolódhatnak, és maguk mögött hagyhatják a mindennapi problémákat. Ezenkívül többen említették azt is, hogy szeretik elolvasni a könyv fülszövegét, s ha az felkelti az érdeklődésüket, akkor elolvassák azt. A korábbi strukturált interjú keretei között az alábbi válaszokat adták arra a kérdésre, hogy mi motiválja öket, miért olvasnak (1. 2. ábra). Az érdekesebb válaszokat szó szerint idézzük.

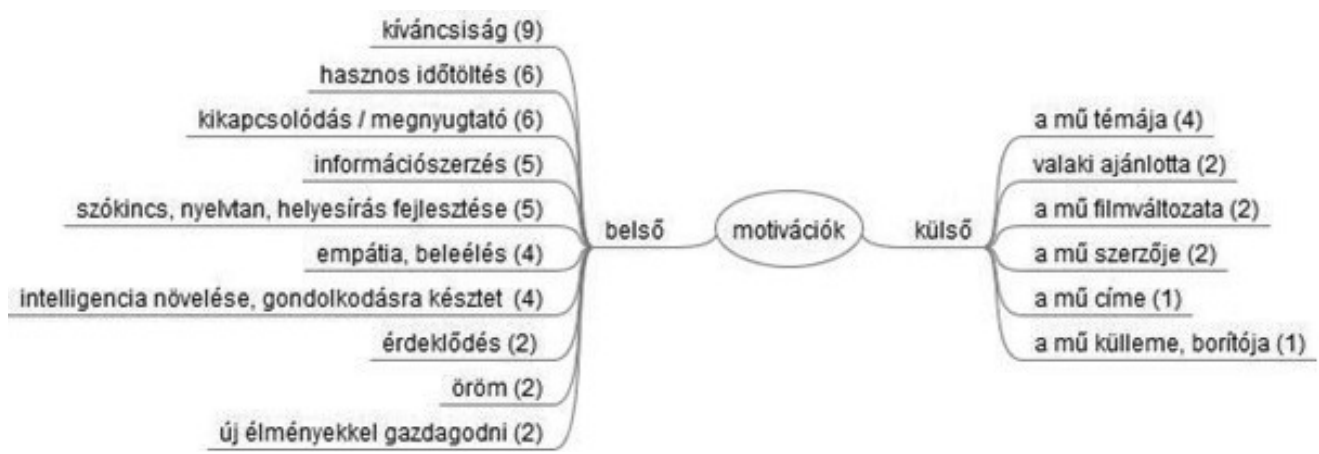

2. ábra: A diákok olvasási motivációi (2012)

A belső motivátorok közül a következőket említették:

- kíváncsiság:

„...kíváncsi vagyok, hogy mi történik a világban vagy más emberekkel.” „Általában nem unalomüzésképpen, hanem inkább a kíváncsiságom kielégitése érdekében."

- hasznosan, értelmes tevékenységgel eltölteni a szabadidőt:

„,...mert szerintem értelmesebb dolog, mint mondjuk leülni Facebookozni, chatelgetni, vagy bármi ilyesmi, amit a mai fiatalok csinálnak, azért olvasok, mert szeretem, mert nagy a fantáziám, és mert érdekelnek a könyvek."

„Hogy ne fölöslegesen töltsem el a kevés szabadidömet, ami van, azt is úgy akarom kihasználni, hogy az hasznos legyen, hogy olyankor se feltétlenül csak punnyadjak valahol, hanem értelmesen töltsem el az idöt.

„,Megunom, ami az interneten zajlik, és olyankor jön a könyv, vagy van valami téma, ami megfog, vagy láttam egy filmet, és tudom, hogy megvan könyvben is, azt elolvasom." 
- információszerzés

- kikapcsolódás:

„Talán az, hogy egy jól megválasztott könyvvel ki tudom kapcsolni az agyamat, és néha erre a tanulás mellett szükség van. Belépni egy más világba, amely nem a tanulásról szól."

- empátia, beleélés:

„, beleképzelhetem magamat a föszereplö világába, és ez új távlatokat nyit meg elöttem, ami kicsit érdekesebb a mai világhoz képest."

„...ha olvasok egy könyvet, akkor megpróbálom úgy értelmezni a történetet, mintha ez valóságos lenne és én is benne lennék."

- Szókincs bővítése „,...hogy bövüljön a szókincsem, javuljon a kifejezö képességem ...”

- Intelligencia növelése „,...minél többet olvas az ember, annál intelligensebb..." Szeretném pallérozni az elmémet."

- érdeklődés, hobbi

- öröm

- Új élményekkel gazdagodni: „,...hogy új élményeket szerezzek a könyvek által...” ,....szeretek új és izgalmas történeteket felfedezni."

- gondolkodásra késztet:

„Engem ami motivál, az az, hogy tényleg kikapcsolja az embert, és tényleg oda tud figyelni utána sok dologra, meg el tud olvasás közben gondolkodni.',

- Nyelvtan, helyesírás fejlesztése

- Megnyugtat

A külső motivátorok közül a következőket tartották fontosnak:

- a mü témája:

„A téma motivál, amit szeretek, és érdekel, azt szívesen olvasom."

- valaki ajánlotta:

„,...ha többektöl hallom, hogy az adott könyv nagyon jó. ,

„, az unokatestvérem ajánlja a könyveket, és amelyeket érdekesnek tartom, azokat elolvasom." 
- a könyv filmváltozata:

„Amikor belekezdek egy könyvbe, annak vannak elözményei: vagy láttam filmen, és azért érdekel, vagy érdekel az alapsztori..."

- a mü címe:

„Egy adott könyv elolvasásánál a mü címe motivál. Ha figyelemfelkeltö és érdekes, akkor furdalni kezdi a kiváncsiság az oldalam, hogy vajon miröl szólhat a mü."

- a mü szerzője:

„,...érdekel az adott téma, vagy az iróról hallottam több információt, illetve leginkább amiatt, mert fogékony vagyok a müvészetek iránt. Meg hát szeretem úgy elképzelni a dolgokat, beindítja a gondolatokat, a képzeletet."

- a könyv külleme, borítója:

„Ha találok egy jó könyvet, akkor elöször a tartalma, címe meg a kinézete buzdit arra, hogy elkezdjem. Hogyha épp izgalmas, akkor nem tudom abbahagyni, meg kell tudnom, mi a vége."

Vélemény a kötelezö olvasmányokról

Az egyetlen téma, amiben egységes véleményt képviseltek a fókuszcsoportos beszélgetés résztvevői, a kötelező olvasmányok voltak. Egyöntetü negatív attitüddel viszonyulnak az iskolai kötelezők olvasmányokhoz, jellemzően nem olvassák el öket, „rájuk erőszakolt” könyveknek nevezik öket. További problémaként vetették fel, hogy nem értik őket, mert bonyolult a nyelvezetük vagy sok régies kifejezést tartalmaznak, illetve a témájuk is érdektelen számukra, nem szólítják meg öket. Egyetlen pozitív példaként A Pál utcai fiúkat emelték ki, mert az abban szereplök, problémáik tényleg az ö korosztályukról, korosztályuknak szólnak.

Az alábbi véleményeket a Rómeó és Júliáról mondták a diákok:

„... ha pl. a Rómeó és Júliát vesszük, csak azt látják, hogy a szüleim nem fogadják el azt, akit szeretek, és nem lehetünk együtt, akkor inkább nem olvasom el, mert ugyanaz megvan az én életemben is.'

„A Rómeó és Júlia nagyon csöpögös szerintem. Egyszerüen annyi benne az érzelem, hogy nem birja befogadni az ember. Én nemrég láttam a szindarabot, s hát tetszett, meg nem volt vele bajom, de megölik egymást, meg szerelem meg nem lehetnek együtt, meg öngyilkosság is van benne, tehát nekem ez sok." 
A kötelező olvasmányokról 2012-ben sem formáltak kedvezőbb véleményt a megkérdezettek, ahogyan a 3. ábrán megjelenített kategóriák is mutatják. A strukturált interjúk keretében azért voltak a kötelezők mellett érvelők is, akik azt emelték ki, hogy az iskolában feladott müvek révén olyan témákkal ismerkedhetnek meg, melyekkel egyébként biztosan nem találkoztak volna. Mellettük szól az is, hogy azok, akik szabad idejükben egyáltalán nem vesznek könyvet a kezükbe, legalább a kötelezőket kénytelenek elolvasni. Mások azért tartják fontosnak őket, mert ismeretük hozzátartozik az alapmüveltséghez, és mert sok klasszikus, értékes olvasmány található köztük. A megkérdezettek többségének (beleértve a kedvtelésből rendszeresen olvasókat is) véleménye azonban inkább elmarasztaló a kötelező olvasmányokat illetően. Érveik között gyakran szerepelt, hogy egy olyan müvet, amelynek elolvasására kötelezik őket, kevésbé szívesen olvasnak, mint az olyat, amelyet maguk választhatnak meg. A negatívumaik közé tartozik még az unalmas vagy érdektelen téma, a nehezen érthető cselekmény, mely sokszor a régies, nehézkes nyelvezetnek köszönhetö, hogy nem aktuálisak, nem tartalmaznak hasznosítható ismereteket a jelen kor emberének, nem az ö korosztályuknak íródtak, nem olyan problémákat vetnek fel, amelyek őket érintik és érdekelhetik, hosszúak, és akár el is vehetik a kedvet az olvasástól.

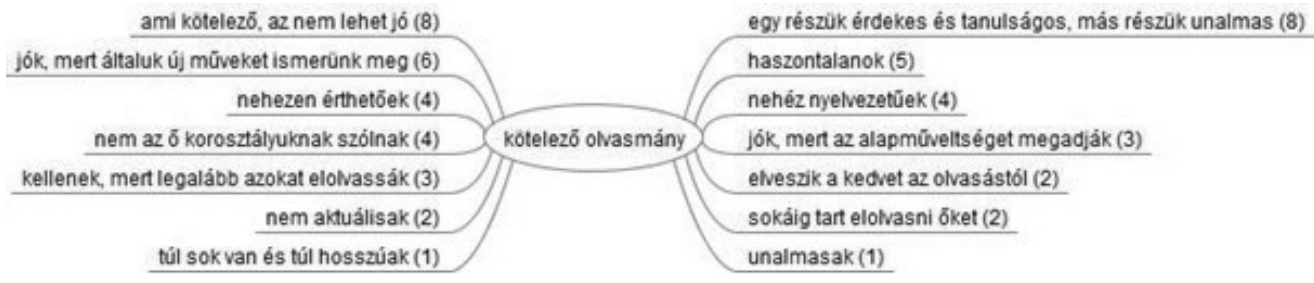

3. ábra: A tanulók véleménye a kötelezö olvasmányokról (2012)

\section{Utoljára olvasott könyvek}

A jelenleg, illetve utoljára olvasott könyvek között a következöket említették a beszélgetés résztvevői: Darren Shan: Zom-B Alvilág; Borsa Brown: Az arab; Lakatos Levente: Szeress jobban; Tizenhárom okom volt; Kim Harrington: A hatodik érzék; Kelly Oram: Cinder és Ella; Anna Todd: After; Meg Cabot (és mások): Pokoli báléjszakák; Stephenie Meyer: Alkonyat - Újhold; Cecelia Ahern: Ahol a szivárvány véget ér; Suzanne Collins: Az éhezők viadala; John Green: Csillagainkban a hiba; Rowling: Harry Potter sorozat; Leiner Laura: Szent Johanna gimi; Bexi; Cassandra Clare: A végzet ereklyéi. A paletta hasonlít a 2012-ben említettekhez, hiszen a populáris irodalom most is meghatározó 
alakítója a diákok ízlésvilágának, de az öt évvel ezelőtti beszélgetések során többen említettek klasszikusokat is (1. 4. ábra).

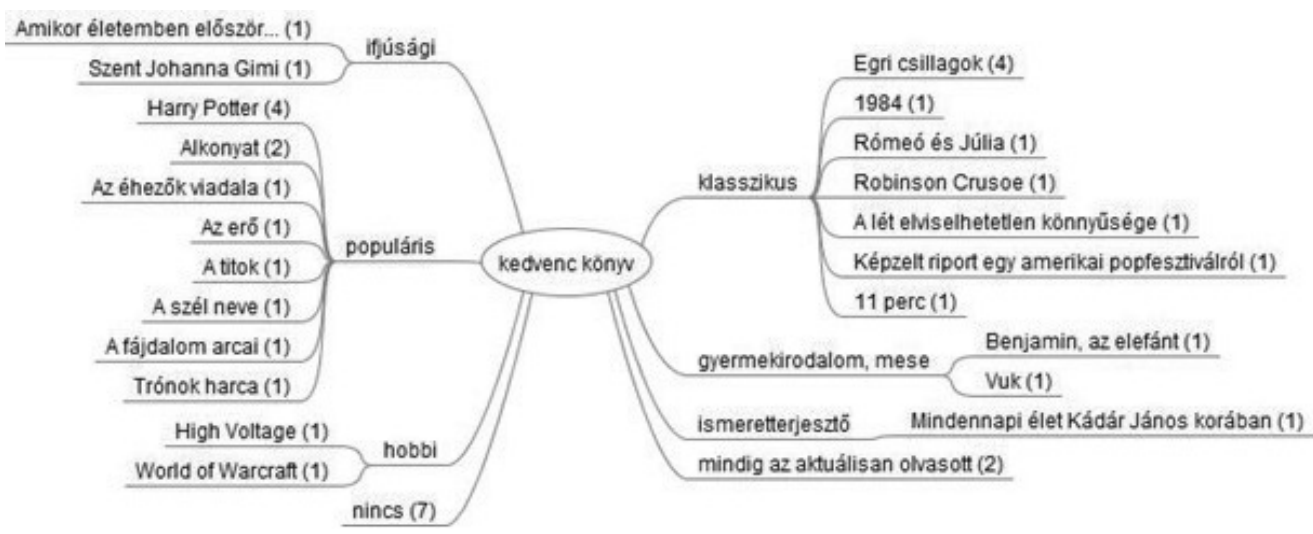

4. ábra: A tanulók kedvenc könyvei (2012)

\section{Összegzés}

Összességében tehát elmondható, hogy a két vizsgálat között öt év telt el, másmás kontextusban zajlottak, ami némileg befolyásolta a válaszadást. 2012-ben egyenként beszélgettünk negyven középiskolás diákkal, ennek hatására árnyaltabb, részletesebb képet kaptunk az olvasási szokásokról és attitüdökről. Nagyobb arányt képviseltek akkor az olyan válaszok, amelyek például pozitív tartalommal bírtak a kötelező olvasmányokra vonatkozóan, illetve interperszonális kontextusban sokkal inkább említettek klasszikus irodalmi müveket is a kedvelt olvasmányok között. Abban a mostani beszélgetés is megerősített bennünket, hogy a mai fiatalok is olvasnak, de olvasásuk eltér a hagyományos (pusztán papíralapú) olvasástól. A vizsgált tanulók szabadidő-struktúrája különbözik a tíz, húsz vagy harminc évvel ezelőttitől. Szabadidős tevékenységeikben kiemelt szerep jut az infokommunikációs eszközöknek, elsősorban a számítógép- és internethasználatnak, az okostelefonoknak, de a televíziózásnak, filmnézésnek, zenehallgatásnak is. Ennek hatására a kedvtelésböl történő olvasásra kevesebb idő jut, és az olvasás jellege is megváltozik: a papíralapú információkeresésröl a hangsúly egyre inkább az elektronikus szövegekre helyeződik. Olvasói ízlésük is más, mint a megelöző generációké volt. Ahogyan a televíziós müsorokban is jobban kedvelik a humoros, zenés, szórakoztató, akciódús, izgalmat, rejtélyt tartalmazó produkciókat, vagy a filmek közül is előnyben részesítik a humoros, kalandos, borzongató, fantáziadús alkotásokat, 
úgy ezek a tendenciák a kedvelt olvasmányaik jellegében is megmutatkoznak. Mindenesetre elgondolkodtató, hogy olvasói ízlésük, érdeklődési körük, s napi rutinjuk is mennyire távol áll a kötelező olvasmányok élmény-és gondolatvilágától, s egyre inkább hajlunk arra, amit már többek között Fenyő D. György és Arató László is megfogalmaztak, hogy szükség van a kötelező irodalmi kánon felülvizsgálatára, megváltoztatására.

\title{
Felhasznált irodalom
}

Magyarné Fazekas Ágnes (2013): Vizsgálatok 15-16 éves tanulók olvasási és médiahasználati szokásairól. Doktori $(\mathrm{PhD})$ disszertáció.

\begin{abstract}
In this study, we summarize the main consequences of a round table conversation. We talked with secondary school children about their reading habits, attitudes and reading experiences on the $29^{\text {th }}$ September 2017, at the Researchers' Night. During the conversation, the children answered the following questions: who, what, when, how, where, why and in whatever form do they like reading? Which are the determinate factors? The story? The author? The size? The genre? All of them? None of them? Anything else? We compared the students' opinions with the results of a research from 2012, which we made also among secondary school-children, with the method of structured interviews.
\end{abstract}

